\title{
TINJAUAN YURIDIS KEDUDUKAN HUKUM PARA PIHAK DALAM PERJANJIAN TERAPEUTIK
}

\author{
Evy Savitri Gani \\ Fakultas Syariah Dan Ekonomi Islam IAIN Ambon \\ Email: evysavitrigani@gmail.com
}

\begin{abstract}
ABSTRAK:
Tulisan ini mengkaji permasalahan kedudukan hukum para pihak dalam perjanjian terapeutik. Permasalahan dalam tulisan ini adalah bagaimana kedudukan hukum para pihak dalam perjanjian terapeutik dan bagaimanakah perlindungan hukum bagi pasien dalam perjanjian terapeutik. Data dikumpulkan melalui penelaah undangundang, buku atau literatur dan dianalisis secara deskripstif kualitatif. Hasil penelitian menunjukan bahwa kedudukan para pihak antara pasien dan dokter menurut hukum sama atau seimbang. Hal ini tercermin dari hak dan kewajiban yang diatur dalam peraturan perundangundangan di bidang kesehatan. Sedangkan bentuk perlindungan hukumnya juga tercermin dalam Undang-Undang Nomor 36 Tahun 2009 Tentang Kesehatan, Undang-Undang Nomor 29 Tahun 2004 Tentang Praktek Kedokteran dan Undang-Undang Nomor 8 Tahun 1999 Tentang Perlindungan Konsumen.

Kata kunci: kedudukan hukum, dokter dan pasien, perjanjian terapeutik
\end{abstract}

\begin{abstract}
:
This paper examines the legal status of the parties to the therapeutic agreement. The problem in this paper is how the legal status of the parties to the treaty is therapeutic and what is the legal protection for the patient in the therapeutic covenant. Data were collected through review of laws, books or literature and analyzed descriptively qualitatively. The results showed that the position of the parties between patients and doctors according to law equal or balanced. This is reflected in the rights and obligations set forth in the legislation in the field of health. While the form of legal protection is also reflected in Law Number 36 Year 2009 on Health, Law Number 29 Year 2004 About Medical Practice and Law Number 8 Year 1999 About Consumer Protection.

Keywords: legal status, doctor and patient, therapeutic agreement
\end{abstract}

\section{Pendahuluan}

Kesehatan merupakan faktor yang sangat penting dalam kehidupan manusia. Kondisi yang sehat menjadi peluang bagi manusia bisa hidup dengan produktif untuk menghasilkan sesuatu yang bermanfaat bagi hidupnya. Karena itu kesehatan merupakan suatu kebutuhan yang sangat vital.

Salah satu upaya yang dilakukan pemerintah untuk menciptakan kondisi kesehatan yang baik adalah dengan mengeluarkan peraturan perundang-undangan di 


\section{Tahkím}

Vol. XIV, No. 2, Desember 2018

bidang kesehatan yaitu Undang-Undang RI Nomor 23 Tahun 1992 Tentang Kesehatan yang telah dirubah menjadi Undang-Undang RI Nomor 36 Tahun 2009 Tentang Kesehatan, Undang-Undang Nomor 29 Tahun 2004 Tentang Praktek Kedokteran dan Undang-Undang Nomor 36 Tahun 2014 Tentang Tenaga Kesehatan.

Semakin pesatnya pertumbuhan manusia, akan semakin kompleks pula masalah yang dialaminya. Salah satu masalah utama terkait kesehatan yaitu pelayanan kesehatan yang diberikan kepada dokter kepada pasien. Hubungan antara pasien dan dokter itu merupakan hubungan kontraktual atau perikatan yang berdasarkan pada perjanjian. Hubungan kontraktual antara dokter dan pasien disebut kontrak teraupetik. ${ }^{1}$

Hubungan kontraktual tersebut kemudian melahirkan banyak persoalan. Persoalan-persoalan yang timbul lebih banyak menyangkut pelayanan rumah sakit yang kurang baik atau tindakan malapraktek yang dilakukan oleh dokter kepada pasien. Seharusnya masing-masing pihak mengetahui apa yang menjadi hak dan kewajibannya masing-masing sehingga dapat meminimalisir persoalan yang terjadi.

Berdasarkan dari uraian di atas, makalah ini bertujuan untuk mengkaji tinjauan yuridis kedudukan hukum antara pasien dan dokter dalam perjanjian terapeutik.

\section{Tinjauan Umum Tentang Perjanjian}

Menurut R. Subekti, "perjanjian adalah suatu peristiwa dimana ada seseorang berjanji kepada seorang lain atau dua orang itu saling berjanji untuk melaksanakan suatu hal."2 Hubungan kedua orang yang bersangkutan mengakibatkan timbulnya suatu ikatan yang berupa hak dan kewajiban kedua belah pihak atas suatu prestasi.

Pasal 1313 KUH Perdata menyebutkan bahwa "suatu perjanjian adalah suatu perbuatan dengan mana satu orang atau lebih mengikatkan dirinya terhadap satu orang lain atau lebih. ${ }^{3}$ Pasal ini menerangkan secara sederhana tentang pengertian perjanjian yang menggambarkan tentang adanya dua pihak yang saling mengikatkan diri. Pengertian ini sebenarnya tidak begitu lengkap, tetapi pengertian ini menunjukkan, bahwa dalam perjanjian itu terdapat satu pihak mengikatkan diri kepada pihak lain. ${ }^{4}$

Dalam hukum perjanjian dikenal banyak asas, di antaranya sebagai berikut: ${ }^{5}$

1. Asas konsensualisme

Dalam hukum perjanjian berlaku asas yang dinamakan asas konsensualisme. Istilah ini berasal dari bahasa latin ialah consensus yang artinya sepakat. ${ }^{6}$ Asas

${ }^{1}$ Sofwan Dahlan, Hukum Kesehatan (Cet. 3; Semarang: Badan Penerbit Universitas Diponegoro, 2003), h. 33 .

${ }^{2}$ Mohdar Yanlua dan Evy Savitri Gani, Hukum Dagang (Magetan: Media Guru, 2015), h. 47.

${ }^{3}$ Lihat pasal 1313 KUH Perdata

${ }^{4}$ Ahmadi Miru dan Sakka Pati, Hukum Perikatan. Penjelasan Makna Pasal 1233 Sampai Pasal 1456, (Jakarta; Raja Grafindo Persada, 2008), h. 63.

${ }^{5}$ Ibid., h 3-7

${ }^{6}$ H. Hari Saherodji, Pokok-Pokok Hukum Perdata (Jakarta; Aksara Baru, 1980), h. 88 


\section{Tabkím}

Vol. XIV, No. 2, Desember 2018

konsesualisme sering diartikan bahwa dibutuhkan kesepakatan untuk lahirnya suatu kesepakatan.

2. Asas kebebasan berkontrak

Asas kekebasan berkontrak merupakan asas yang sangat penting dalam hukum kontrak. Asas ini bermakna bahwa setiap orang bebas membuat perjanjian dengan siapapun, apapun isinya, apapun bentuknya sejauh tidak melanggar undang-undang, ketertiban umum, dan kesusilaan. ${ }^{7}$

3. Asas mengikatnya kontrak (Pacta Sunt Servanda)

Setiap orang yang membuat kontrak, dia terikat untuk memenuhi kontrak tersebut karena kontrak tersebut mengandung janji-janji yang harus dipenuhi dan janji tersebut mengikat para pihak sebagaimana mengikatnya suatu undang-undang.

4. Asas itikad baik

Asas itikad baik merupakan asas yang dikenal dalam hukum perjanjian. Ketentuan tentang itikad baik ini diatur dalam pasal 1338 ayat (3) bahwa perjanjian harus dilaksanakan dengan itikad baik.

5. Asas Kepribadian

Asas kepribadian adalah asas yang menentukan ketika seseorang membuat perjanjian dengan orang lain, maka yang terikat dalam perjanjian tersebut hanyalah para pihak yang membuatnya saja.

Kontrak lahir jika disepakati tentang hal-hal yang pokok atau unsur esensial dalam suatu kontrak. Penekanan tentang unsur yang esensial tersebut karena selain unsur yang esensial masih dikenal unsur lain dalam suatu kontrak. Dalam suatu kontrak dikenal dikenal tiga unsur, yaitu sebagai berikut:

1. Unsur esensiali

Unsur esensalia merupakan unsur yang harus ada dalam suatu kontrak karena tanpa adanya kesepakatan tentang unsur esensalia ini maka tidak ada kontrak.

2. Unsur naturalia

Unsur naturalia merupakan unsur yang telah diatur dalam undang-undang sehingga apabila tidak diatur oleh para pihak dalam kontrak, undang-undang yang mengaturnya.

3. Unsur aksidentalia

Unsur aksidentalia merupakan unsur yang nanti ada atau mengikat para pihak jika para pihak memperjanjikannya. ${ }^{8}$

Dalam hukum Eropa Kontinental, syarat sahnya perjanjian diatur dalam Pasal 1320 KUH Perdata atau Pasal 1365 Buku IV NBW (BW Baru) Belanda. ${ }^{9}$ Pasal 1320 KUH Perdata menentukan empat syarat sahnya perjanjian, antara lain: ${ }^{10}$

${ }^{7}$ Lihat pasal 1337 dan 1338 KUH Perdata

${ }^{8}$ Ahmadi Miru, Hukum Kontrak. Perancangan Kontrak ((Jakarta, Raja Grafindo Persada, 2007), h. 31-32. 


\section{Tahkím}

Vol. XIV, No. 2, Desember 2018

\section{Adanya kata sepakat (Toestemming)}

Kesepakatan berarti persesuaian kehendak, namun kehendak atau keinginan ini harus dinyatakan. Menyatakan kehendak ini tidak terbatas pada mengucapkan perkataan-perkataan, ia dapat dicapai pula dengan memberikan tanda-tanda apa saja yang dapat menterjemahkan kehendak itu, baik oleh pihak yang mengambil prakarsa yakni pihak yang menawarkan (melakukan offerte) maupun oleh pihak yang menerima penawaran tersebut. ${ }^{11}$

2. Kecakapan bertindak

Kecakapan bertindak adalah kecakapan atau kemampuan untuk melakukan perbuatan hukum. Perbuatan hukum adalah perbuatan yang akan menimbulkan akibat hukum. Orang-orang yang akan mengadakan perjanjian haruslah orang-orang yang cakap dan mempunyai wewenang untuk melakukan perbuatan hukum, sebagaimana ditentukan oleh undang-undang. ${ }^{12}$

3. Suatu hal tertentu

Suatu hal tertentu ini diatur dalam Pasal 1333 KUH Perdata. Pasal 1333 KUH Perdata menyebutkan bahwa suatu perjanjian harus mempunyai sebagai pokok suatu barang yang paling sedikit ditentukan jenisnya.

4. Sebab yang terlarang

Mengenai sebab yang terlarang diatur dalam pasal 1335, pasal 1336, dan pasal 1337 KUH Perdata. Suatu sebab adalah terlarang, apabila dilarang oleh undangundang atau apabila berlawanan dengan kesuliaan baik atau ketertiban umum. Suatu sebab dinyatakan terlarang atau biasa disebut sebab tidak halal apabila bertentangan dengan undang-undang, kesuliaan dan ketertiban umum.

Menurut ketentuan pasal 1338 KUH Perdata, perjanjian yang dibuat secara sah, yaitu memenuhi syarat-syarat pasal $1320 \mathrm{KUH}$ Perdata berlaku sebagai undang-undang bagi mereka yang membuatnya, tidak dapat ditarik ditarik kembali tanpa persetujuan kedua belah pihak atau karena alasan-alasan yang cukup menurut undang-undang, dan harus dilaksanakan dengan itikad baik. ${ }^{13}$

Dalam perjanjian terdapat suatu keadaan yang sering terjadi yaitu wanprestasi. Wanprestasi berasal dari perkataan Belanda yang berarti suatu keadaan yang menunjukkan debitur tidak berprestasi (tidak melaksanakan kewajibannya) dan dia dapat dipersalahkan. Ada empat macam bentuk wanprestasi, yaitu: 2010), h. 33

${ }^{9}$ Salim H.S., Hukum Kontrak, Teori dan Teknik Penyusunan Kontrak (Jakarta: Sinar Grafika,

${ }^{10}$ Lihat pasal 1320 KUH Perdata

${ }^{11}$ Djoko Prakoso dan Bambang Riyadi Lany, Dasar Hukum Persetujuan Tertentu di Indonesia (Jakarta: Bina Aksara, 1987), h. 4-5

${ }^{12}$ Salim H.S., op.cit., h. 33-34.

${ }^{13}$ Abdulkadir Muhammad, Hukum Perikatan (Bandung: Citra Aditya Bakti, 1992), h. 96-99 


\section{Tahkím}

Vol. XIV, No. 2, Desember 2018

a. Tidak berprestasi sama sekali atau berprestasi tapi tidak bermanfaat lagi atau tidak dapat diperbaiki.

b. Terlambat memenuhi prestasi.

c. Memenuhi prestasi secara tidak baik atau tidak sebagaimana mestinya

d. Melakukan sesuatu namun menurut perjanjian tidak boleh dilakukan. ${ }^{14}$

Berakhirnya kontrak merupakan selesai ataui hapusnyanya sebuah kontrak yang dibuat dua pihak, yaitu pihak kreditur dan debitur tentang sesuatu hal. Pihak kreditur adalah pihak atau orang yang berhak atas suatu prestasi. Sedangkan debitur adalah pihak yang berkewajiban untuk memenuhi prestasi. Berakhirnya perikatan diatur dalam Pasal 1381 KUH Perdata. Pasal tersebut menyebutkan bahwa :Perikatan-perikatan hapus:
a. Karena pembayaran;
b. Karena penawaran pembayaran tunai diikuti dengan penyimpanan atau penitipan;
c. Karena pembaruan utang;
d. Karena perjumpaan utang atau kompensasi;
e. Karena percampuran utang;
f. Karena pembebasan utangnya;
g. Karena musnahnya barang barang yang terutang;
h. Karena kebatalan atau pembatalan;
i. Karena berlakunya suatu syarat batal; dan
j. Karena lewatnya waktu.

\section{Tinjauan Umum Tentang Perjanjian Terapeutik}

Perjanjian terapeutik atau Kontrak terapeutik merupakan kontrak yang dikenal dalam pelayanan kesehatan. Istilah kontrak terapeutik merupakan terjemahan dari Bahasa Inggris, yaitu therapeutic contract. Para ahli di bidang hukum kesehatan telah memberikan pengertian tentang kontrak terapeutik. Fred Ameln mengartikan kontrak terapeutik sebagai "kontrak dimana pihak dokter berupaya secara maksimal menyembuhkan pasien (inspaningsverbintenis) jarang merupakan resultaasverbintenis."15 Dalam defenisi ini kontrak terapeutik disamakan dengan inspaningsverbintenis karena dalam kontrak ini dokter hanya berusaha untuk menyembuhkan pasien dan upaya yang dilakukan belum tentu berhasil. Para pihaknya dalam kontrak ini adalah dokter dan pasien. ${ }^{16}$

Sedangkan menurut Veronica Komalawati, transaksi terapeutik adalah hubungan hukum antara dokter dan pasien dalam pelayanan medis secara professional,

\footnotetext{
${ }^{14}$ Handri Raharjo, Hukum Perjanjian di Indonesia (Jakarta: Pustaka Yustisia, 2009), h. 79-81

${ }^{15}$ H. Salim H.S., Perkembangan Hukum kontrak di Luar KUH Perdata (Jakarta: PT Raja Grafindo Persada, 2006), h. 45

${ }^{16}$ Ibid.
} 


\section{Tahkím}

Vol. XIV, No. 2, Desember 2018

didasarkan kompetensi yang sesuai dengan keahlian dan ketrampilan tertentu di bidang kedokteran. ${ }^{17}$

Pada Mukadimah Kode Etik Kedokteran Indonesia yang tertuang dalam Keputusan Menteri Kesehatan RI Nomor 434 /Men.Kes /X / 1983 tentang Berlakunya Kode Etik Kedokteran Indonesia Bagi Para Dokter di Indonesia, dicantumkan tentang perjanjian terapeutik, bahwa "Yang dimaksud perjanjian terapeutik adalah hubungan antara dokter dengan pasien dan penderita yang dilakukan dalam suasana saling percaya (konfidensial), serta senantiasa diliputi oleh segala emosi, harapan dan kekhawatiran makhluk insani." 18

Hermien Hadiati Koeswadji mengemukakan pengertian kontrak terapeutik. Dia menggunakan istilah transaksi terapeutik untuk kontrak terapeutik. Menurutnya transaksi terapeutik adalah "transaksi untuk menentukan mencari terapi yang paling tepat bagi pasien oleh dokter. Dalam transaksi terapeutik tersebut kedua belah pihak harus memenuhi syarat-syarat tertentu, dan bila transaksi sudah terjadi maka kedua belah pihak terikat akan hak dan kewajiban sebagaimana yang telah disepakati oleh keduanya."19

Apabila kedua definisi di atas dianalisa, maka yang menjadi para pihak dalam kontrak terapeutik adalah pasien dan dokter. Dalam Undang-Undang RI Nomor 36 Tahun 2009 Tentang Kesehatan, para pihaknya pasien dan tenaga kesehatan, sedangkan dalam Undang-Undang RI Nomor 29 Tahun 2009 tentang Praktek Kedokteran, para pihaknya adalah pasien, dokter, dan dokter gigi. Dengan demikian, kedua definisi di atas perlu disempurnakan. Menurut Salim H.S, bahwa yang diartikan dengan kontrak terapeutik adalah "kontrak yang dibuat antara pasien dengan tenaga kesehatan dan/atau dokter atau dokter gigi, dimana tenaga kesehatan dan/atau dokter atau dokter gigi berusaha untuk melakukan upaya maksimal untuk melakukan penyembuhan terhadap pasien sesuai dengan kesepakatan yang dibuat antara keduanya, dan pasien berkewajiban untuk membayar biaya penyembuhannya." 20

Subjek dalam kontrak terapeutik meliputi pasien, tenaga kesehatan/dokter/ dokter gigi. Objek dalam kontrak terapeutik adalah upaya maksimal untuk melakukan penyembuhan terhadap pasien. Kewajiban pasien adalah membayar biaya atau jasa terhadap tenaga kesehatan/dokter atau dokter gigi. Besarnya biaya atau jasa itu ditentukan secara sepihak oleh tenaga kesehatan/dokter/dokter gigi, sementara pasien sendiri tidak mempunyai kekuatan untuk tawar-menawar terhadap apa yang disampaikan oleh tenaga kesehatan/dokter/dokter gigi. ${ }^{21}$

\footnotetext{
${ }^{17}$ Veronica Komalawati, Peranan Informed Consent dalam Transaksi Terapeutik (Bandung: PT. Citra Aditya Bakti, 1999), h.1.

${ }^{18}$ Perjanjian terapeutik diakses pada http://4lhamid.blogspot.co.id/2012/12/kontrak-perjanjianterapeutik.html (diakses tanggal 29 November 2017 pukul 18.00 wit).

${ }^{19}$ H. Salim HS, Perkembangan Hukum kontrak di Luar KUH Perdata, h. 45.

${ }^{20}$ Ibid.

${ }^{21}$ Ibid., h. 47
} 


\section{Tahkím}

Vol. XIV, No. 2, Desember 2018

Peraturan perundang-undangan yang mengatur tentang kontrak terapeutik dapat dikaji dan dianalisis dalam berbagai ketentuan berikut:

1. Buku III KUH Perdata

2. Undang-Undang RI Nomor 36 Tahun 2009 Tentang Kesehatan

3. Undang-Undang RI Nomor 29 Tahun 2004 tentang Praktik Kedokteran

4. Peraturan Menteri Kesehatan RI Nomor 290/MENKES/ PERIII/2008 Tentang Persetujuan Tindakan Kedokteran. ${ }^{22}$

Dalam Undang-Undang RI Nomor 36 Tahun 2009 Tentang Kesehatan telah ditentukan para pihak yang terkait dalam pelayanan kesehatan yaitu pasien dan tenaga kesehatan. Tenaga kesehatan adalah setiap orang yang mengabdikan diri dalam bidang kesehatan serta memiliki pengetahuan dan/atau keterampilan melalui pendidikan di bidang kesehatan yang untuk jenis tertentu memerlukan kewenangan untuk melakukan upaya kesehatan. $^{23}$

Sebenarnya dalam Undang-Undang RI Nomor 36 Tahun 2009 Tentang Kesehatan tidak dicantumkan pengertian dari dokter, hanya terdapat pengertian tenaga kesehatan, tapi tersirat ada pihak dokter dalam undang-undang tersebut. Dari pengertian tenaga kesehatan tersebut, dapat ditarik tiga ciri tenaga kesehatan antara lain:

1. orang yang mengabdikan diri dalam bidang kesehatan

2. memiliki pengetahuan dan/atau keterampilan melalui pendidikan di bidang kesehatan

3. memerlukan kewenangan untuk melakukan upaya kesehatan.

Dalam Undang-Undang RI Nomor 29 Tahun 2004 tentang Praktek Kedokteran lebih spesifik menentukan para pihak dalam kontrak terpeutik yaitu pasien dengan dokter dan dokter gigi. Menurut pasal 1 Angka 2 Undang-Undang RI Nomor 29 tahun 2004 Tentang Praktek Kedokteran, dokter adalah dokter, dokter spesialis, dokter gigi dan dokter gigi spesialis lulusan pendidikan kedokteran atau kedokteran gigi baik di dalam maupun di luar negeri yang diakui oleh pemerintah RI sesuai dengan peraturan perundang-undangan.

Sedangkan menurut pasal 1 angka 10 Undang-Undang RI Nomor 29 tahun 2004 Tentang Praktek Kedokteran, pasien adalah setiap orang yang melakukan konsultasi masalah kesehatannya untuk memperoleh pelayanan yang diperlukan baik secara langsung maupun secara tidak langsung kepada dokter atau dokter gigi.

Karena transaksi terapeutik merupakan bagian pokok dari upaya kesehatan, yaitu berupa pemberian Pelayanan kesehatan yang didasarkan atas keahlian, keterampilan serta ketelitian, maka tujuannya tidak dapat dilepaskan dari tujuan ilmu

\footnotetext{
${ }^{22} \mathrm{Ibid}$.

${ }^{23}$ Pasal 1 angka 6 Undang-Undang RI Nomor 36 Tahun 2009 Tentang Kesehatan
} 


\section{Tahkím}

Vol. XIV, No. 2, Desember 2018

kesehatan yaitu untuk: (1) menyembuhkan dan mencegah penyakit; (2) meringankan penderitaan; dan (3) mendampingi pasien. ${ }^{24}$

\section{Kedudukan Hukum Para Pihak Dalam Perjanjian Terapeutik}

Sebagaimana umumnya dalam suatu perikatan, dalam transaksi terapeutik juga terdapat para pihak yang mengikatkan diri dalam suatu perikatan atau perjanjian yaitu dokter sebagai pihak yang melaksanakan atau memberikan pelayanan medis dan pasien sebagai pihak yang menerima pelayanan medis. Jadi secara umum apa yang diatur dalam perjanjiian menurut Buku III KUH Perdata diatur juga atau berlaku pula dalam perjanjian terapeutik. Hanya saja dalam perjanjian terapeutik, ada kekhususan tertentu, yaitu tentang ikrar atau cara mereka mengadakan perjanjian, sebab dalam perjanjian terapeutik dijelaskan bahwa dengan kedatangan pasien ke tempat praktek atau rumah sakit tempat dokter bekerja, dengan tujuan untuk memeriksakan kesehatannya atau untuk berobat, sudah dianggap ada perjanjian terapeutik. ${ }^{25}$

Dalam hukum perikatan sebagaimana diatur dalam KUH Perdata dikenal adanya dua macam perjanjian, yaitu:

1. Inspanningsverbintenis, yakni perjanjian upaya, artinya kedua belah pihak yang berjanji berdaya upaya secara maksimal untuk mewujudkan apa yang diperjanjikan.

2. Ressultaatverbintenis, yakni suatu perjanjian bahwa pihak yang berjanji akan memberikan suatu resultaat, yaitu semua hasil yang nyata sesuai dengan apa yang diperjanjikan. ${ }^{26}$

Perjanjian antara dokter dengan pasien termasuk pada perjanjian inspaningsverbintenis atau perikatan upaya, sebab dalam konsep ini seorang dokter hanya berkewajiban untuk melakukan pelayanan kesehatan dengan penuh kesungguhan, dengan mengarahkan seluruh kemampuan dan perhatiannya sesuai standart profesinya.

Sebelum menjelaskan mengenai bagaimanakah sebenarnya bentuk hubungan yang timbul diantara pasien dan dokter, menjadi penting untuk mengetahui kapan dimulainya hubungan dokter dan pasien tersebut. Karena pada saat itu sang dokter harus memenuhi kewajiban hukum dan timbulnya tanggung jawab terhadap pasiennya. Pada umumnya di dalam banyak hal, mulainya hubungan tersebut sangat jelas dan nyata. Apabila seorang pasien meminta dokter untuk mengobatinya dan sang dokter menerimanya, maka saat itu sudah dimulai hubungan kontrak antara dokter dan pasien. Hubungan dokter dan pasien dapat dibedakan menjadi:

\footnotetext{
${ }^{24}$ Pengertian Transaksi Terapeutik Definisi Tujuan Dasar Hukum dalam Pelayanan Medis diakses dalam http://www.landasanteori.com/2015/10/pengertian-transaksi-terapeutik.html (diakses tanggal 25 November 2017 pada pukul 20.00 wit)

${ }^{25}$ Bahder Johan Nasution, Hukum Kesehatan (Jakarta: Rineka Cipta, 2005), h. 11-12

${ }^{26}$ Ibid., h. 13.
} 


\section{Tahkím}

Vol. XIV, No. 2, Desember 2018

\section{Hubungan medik}

Dokter adalah pihak yang mempunyai keahlian di bidang kedokteran, sedangkan pasien adalah orang sakit yang membutuhkan bantuan dokter untuk menyembuhkan penyakitnya yang dideritanya. Pada kedudukan ini dokter adalah orang sehat yang juga pakar dalam bidang kedokteran dan pasien adalam orang sakit yang awam mengenai penyakitnya.

Dalam hubungan medik kedudukan dokter dan pasien adalah kedudukan yang tidak seimbang. Pasien karena keawamannya akan menyerahkan kepada dokter tentang penyembuhan penyakitnya, dan pasien diharapkan patuh menjalankan semua nasehat dari dokter dan memberikan persetujuan atas tindakan yang dilakukan dokter. Selain itu dalam hubungan medik ini, dasar dari hubungan antara pasien dan dokter adalah atas dasar kepercayaan dari pasien atas kemampuan dokter untuk berupaya semaksimal mungkin menyembuhkan penyakit yang dideritanya.

Terdapat pula pola yang paternalistic antara dokter dan pasien, dianggap bahwa dokter akan berupaya semaksimal mungkin menyembuhkan pasien, seperti seorang bapak yang baik yang akan berbuat untuk kepentingan anaknya. Pasien diharapkan akan bertindak sebagai anak yang patuh dan percaya bahwa dokter akan bertindak sebagai bapak yang baik. Pola hubungan di atas yaitu antara sehat dan orang sakit, pakar awam, kepercayaan dan paternalistic, menempatkan kedudukan yang tidak seimbang antara pasien dan dokter.

2. Hubungan moral

Seperti yang diketahui ciri dari kaidah-kaidah moral, adalah tekanan pada kewajiban dari pihak yang satu kepada pihak yang lainnya, tanpa membicarakan hak seseorang terhadap pihak lainnya. Maka dalam hubungan social ini, hanya terdapat kewajiban dokter dan kewajiban pasien.

3. Hubungan hukum

Hubungan hukum selalu menimbulkan hak dan kewajiban yang timbal balik. Hak dokter menjadi kewajiban pasien dan hak pasien menjadi kewajiban dokter. Keadaan itru menempatkan kedudukan dokter dan pasien pada posisi kedudukan yang sama dan sederajat. ${ }^{27}$

Dari penjelasan bentuk hubungan dokter dan pasien di atas dapat dipahami, bahwa hubungan antara dokter dan pasien merupakan suatu hubungan yang kompleks, karena didalamnya terdapat hubungan medic, hubungan moral maupun hubungan hukum. Pada hubungan medik dan moral, dokter memiliki kedudukan yang sangat tinggi, karena dokter adalah orang yang sangat tahu tentang penyakit pasien, sedangkan pasien memiliki kedudukan yang sangat lemah yaitu orang yang sedang sakit dan awam dengan penyakitnya. Pasien datang ke rumah sakit atau ke dokter berharap agar

${ }^{27}$ Wila Chandrawila Supriadi, Hukum Kedokteran, (Bandung; Mandar Maju, 2001), h. 27-29 


\section{Tahkím}

Vol. XIV, No. 2, Desember 2018

segera disembuhkan penyakitnya. Pola hubungan ini disebut dengan hubungan paternalistic, sebab dokter dianggap lebih tahu dan mampu mengobati pasiennya.

Dalam perkembangannya, pola hubungan antara dokter dan pasien yang demikian tersebut, lambat laun telah mengalami pergeseran ke arah yang lebih demokratis yaitu kearah hubungan berdasarkan kontraktual. Sebagaimana hubungan kontraktual terdapat hak dan kewajiban yang sama antara kedua belah pihak. Kedudukan dokter tidak lagi dianggap lebih tinggi daripada pasien melainkan kedudukan dokter dan pasien dalam hubungannya tersebut sudah seimbang atau sederajat. Pasien tidak lagi dianggap sebagai objek hukum tetapi pasien sudah sebagai subjek hukum. Pola hubungan ini seperti yang dijelaskan diatas disebut dengan pola hubungan hukum.

Hubungan hukum antara dokter dan pasien menempatkan kedudukan dokter dan pasien berada pada posisi yang sejajar atau seimbang, sehingga setiap apa yang dilakukan oleh dokter terhadap pasien tersebut harus melibatkan pasien dalam menentukan apakah sesuatu tersebut dapat atau tidak dapat dilakukan atas dirinya. Salah satu bentuk keseimbangan dalam hubungan hukum dokter dan pasien adalah melalui informed consent atau persetujuan tindakan kedokteran.

Berdasarkan pasal 1 angka 1 Peraturan Menteri Kesehatan RI Nomor 290/ MENKES/PER/III/2008 Tentang Persetujuan Tindakan Kedokteran, Persetujuan Tindakan Kedokteran adalah persetujuan yang diberikan pasien atau keluarga terdekat setelah mendapat penjelasan secara lengkap mengenai tindakan kedokteran atau kedokteran gigi yang akan dilakukan terhadap pasien.

Kontrak terapeutik merupakan salah satu bentuk perikatan hukum timbal balik. Kedua belah pihak memiliki hak dan kewajiban masing-masing. Pelaksanaan kewajiban dokter adalah menjadi hak pasien. Sebaliknya, kewajiban pasien adalah menjadi hak dokter. Bagi pihak dokter, prestasi melakukan sesuatu adalah kewajiban hukum untuk berbuat (perlakuan medis) dengan sebaik dan semaksimal mungkin bagi kepentingan kesehatan pasien. Kewajiban hukum untuk tidak berbuat salah atau keliru, artinya kewajiban untuk pelayanan kesehatan pasien dengan sebaik-baiknya. Kewajiban melakukan apa yang seharusnya dilakukan dan tidak melakukan segala sesuatu yang seharusnya tidak perlu dilakukan. ${ }^{28}$

Kewajiban dan hak dokter ditetapkan dalam peraturan perundang-undangan, yakni Undang-Undang RI Nomor 29 Tahun 2004 Tentang Praktek Kedokteran, Undang-Undang RI Nomor 36 Tahun 2009 Tentang Kesehatan dan Undang-Undang RI Nomor 36 Tahun 2014 Tentang Tenaga Kesehatan. Selain itu juga terdapat dalam Kode Etik Kedokteran Indonesia (KODEKI).

Menurut Undang-Undang RI Nomor 29 Tahun 2004 Tentang Praktek Kedokteran, hak dokter dan dokter gigi diatur dalam Pasal 50 sedangkan kewajiban

\footnotetext{
${ }^{28}$ Adami Chazawi, Malapraktik Kedokteran (Jakarta: Sinar Grafika, 2016), h. 13.
} 


\section{Tahkím}

Vol. XIV, No. 2, Desember 2018

dokter dan dokter gigi diatur dalam pasal 51, bahwa dokter atau dokter gigi dalam melaksanakan praktik kedokteran mempunyai hak:

1) memperoleh perlindungan hukum sepanjang melaksanakan tugas sesuai dengan standar profesi dan standar prosedur operasional;

2) memberikan pelayanan medis menurut standar profesi dan standar prosedur operasional;

3) memperoleh informasi yang lengkap dan jujur dari pasien atau keluarganya; dan

4) menerima imbalan jasa.

Dokter atau dokter gigi dalam melaksanakan praktik kedokteran mempunyai kewajiban:

1) memberikan pelayanan medis sesuai dengan standar profesi dan standar prosedur operasional serta kebutuhan medis pasien;

2) merujuk pasien ke dokter atau dokter gigi lain yang mempunyai keahlian atau kemampuan yang lebih baik, apabila tidak mampu melakukan suatu pemeriksaan atau pengobatan;

3) merahasiakan segala sesuatu yang diketahuinya tentang pasien, bahkan juga setelah pasien itu meninggal dunia;

4) melakukan pertolongan darurat atas dasar perikemanusiaan, kecuali bila ia yakin ada orang lain yang bertugas dan mampu melakukannya; dan

5) menambah ilmu pengetahuan dan mengikuti perkembangan ilmu kedokteran atau kedokteran gigi.

Sedangkan hak dan kewajiban pasien yang terdapat dalam pasal 53 UndangUndang RI Nomor 29 Tahun 2004 Tentang Praktik Kedokteran, antara lain:

Pasien, dalam menerima pelayanan pada praktik kedokteran, mempunyai hak:

a) mendapatkan penjelasan secara lengkap tentang tindakan medis sebagaimana dimaksud dalam pasal 45 ayat (3);

b) meminta pendapat dokter atau dokter gigi lain;

c) mendapatkan pelayanan sesuai dengan kebutuhan medis;

d) menolak tindakan medis; dan

e) mendapatkan isi rekam medis.

Pasien, dalam menerima pelayanan pada praktik kedokteran, mempunyai kewajiban:

a) memberikan informasi yang lengkap dan jujur tentang masalah kesehatannya;

b) mematuhi nasihat dan petunjuk dokter atau dokter gigi;

c) mematuhi ketentuan yang berlaku di sarana pelayanan kesehatan; dan

d) memberikan imbalan jasa atas pelayanan yang diterima.

Ketentuan hukum yang telah ditentukan secara normatif tentang hak dan kewajiban dokter dan pasien tersebut mengikat kedua belah pihak, dan haruslah ditaati. Walaupun dalam kontrak terapeutik tidak secara eksplisit ditentukan sebagai prestasi 


\section{Tahkím}

Vol. XIV, No. 2, Desember 2018

masing-masing pihak. Melaksanakan kewajiban dokter maupun pasien merupakan prestasi yang ditetapkan undang-undang. ${ }^{29}$

Karena merupakan suatu perjanjian maka perjanjian terapeutik pun harus tunduk pada hukum perikatan yang diatur dalam buku III KUH Perdata. Dengan demikian, untuk sahnya perjanjian tersebut, harus dipenuhi syarat-syarat yang termuat dalam pasal 1320 KUH Perdata, dan akibat yang ditimbulkannya diatur dalam pasal 1338 KUH Perdata, yang mengandung asas pokok hukum perjanjian.

Untuk sahnya perjanjian terapeutik harus dipenuhi syarat-syarat sesuai pasal 1320 KUH Perdata, yaitu:

1. Adanya kesepakatan dari mereka yang saling mengikatkan dirinya.

2. Adanya kecakapan untuk membuat suatu perikatan.

3. Mengenai suatu hal tertentu.

4. Untuk suatu sebab yang halal/diperbolehkan.

Untuk syarat pertama dan syarat kedua yaitu adanya kesepakatan dan kecakapan itu tertuang dalam bentuk informant consent. Informed consent berfungsi sebagai pemenuhan syarat adanya kesepakatan,yang mengandung makna bahwa sejak tercapainya kesepakatan (consensus) diantara para pihak mengenai pokok pokok isi perjanjian,maka perjanjian sudah terjadi. Kedua belah pihak sudah terikat sejak tercapainya kesepakatan, untuk memenuhi kewajiban yang timbul dari perjanjian tersebut dan memperoleh hak haknya sesuai dengan perjanjian atau menurut ketentuan hukum yang berlaku.

Untuk syarat yang kedua yaitu kecakapan yang bermakna kemampuan untuk melakukan perbuatan hukum. Seperti yang telah dijelaskan bahwa seseorang dianggap tidak cakap jika dia belum dewasa dan berada di bawah pengampuan (Dalam keadaan dungu dan sakit gila). Pasien dianggap kompeten berdasarkan usianya apabila Pasien dewasa, yaitu telah berusia 21 tahun atau telah/pernah menikah. Pasien telah berusia 18 tahun, tidak termasuk anak berdasarkan peraturan perundang-undangan.

Untuk syarat ketiga yaitu suatu hal tertentu atau tentang objek perjanjian. Pada penjelasan pasal 1333 KUH Perdata yang dimaksudkan dengan suatu hal tertentu adalah objek perjanjian harus tertentu, setidaknya harus ditentukan. Dalam suatu perjanjian terapeutik, umumnya objeknya adalah usaha penyembuhan, dimana dokter harus berusaha semaksimal mungkin untuk menyembuhkan penyakit pasien. Oeh karena itu, secara yuridis umumnya termasuk inpanning verbintenis, dimana dokter tidak memberikan jaminan kepastian dalam menyembuhkan penyakit tersebut tetapi dengan ikhtiar dan keahlian dokter diharapkan dapat membantu dalam upaya penyembuhan. ${ }^{30}$ Sedangkan untuk syarat keempat yaitu sebab yang halal itu

\footnotetext{
${ }^{29}$ Ibid., h. 20.

${ }^{30}$ Safitri Hariyani, Sengketa Medik. Alternatif Penyelesaian Perselisihan Antara Dokter dan Pasien (Jakarta: Diadit Media, 2005), h. 14
} 


\section{Tahkím}

Vol. XIV, No. 2, Desember 2018

mengharuskan perjanjian terapeutik yang dibuat para pihak tidak boleh bertentangan dengan undang-undang.

Akibat hukum dari suatu perjanjian pada dasarnya lahir dari adanya hubungan hukum karena suatu perikatan, yaitu dalam bentuk hak-hak dan kewajiban-kewajiban masing-masing pihak, baik pihak dokter maupun pihak pasien. Hal ini berlaku juga dengan perjanjian terapeutik. Jika perjanjian terapeutik telah memenuhi syarat sahnya perjanjian, maka semua kewajiban yang timbul mengikat bagi para pihak, baik pihak dokter maupun pihak pasien.

Perjanjian terapeutik yang dibuat oleh dokter dan pasien berlaku sebagaimana undang-undang dimana undang-undang mewajibkan para pihak memenuhi hak dan kewajibannya masing-masing sesuai dengan hal yang diperjanjikan. Kemudian perjanjian terapeutik tersebut tidak dapat ditarik kembali tanpa kesepakatan pihak lain, misalnya seandainya dokter tidak berhasil menyembuhkan pasien, maka ia tidak boleh lepas tanggung jawab dengan mengalihkan pasien kepada teman seprofesinya yang lain tanpa indikasi medis yang jelas. Untuk mengalihkan pasien, dokter yang bersangkutan harus minta persetujuan pasien atau keluarganya. Setelah itu para pihak baik dokter maupun pasien harus sama-sama beritikad baik dalam melaksanakan perjanjian terapeutik.

Penentuan saat berakhirnya hubungan pasien dan dokter adalah penting karena segala hak dan kewajiban yang dibebankan kepada dokter juga akan ikut berakhir. Kecuali sifat dari pengobatannya menentukan lain, maka berakhirnya hubungan menimbulkan mulai timbulnya kewajiban dari pasien untuk membayar untuk pelayanan pengobatan yang diberikan. Dibawah ini diberikan beberapa cara berakhirnya hubungan dokter dan pasien tersebut, yakni:

1) Sembuhnya pasien dari keadaan sakitnya dan sang dokter menganggap tidak diperlukan lagi pengobatan, sehingga tidak ada manfaatnya lagi pasien untuk meneruskan pengobatannya.

2) Dokternya mengundurkan diri

3) Pengakhiran oleh pasien

4) Meninggalnya sang pasien

5) Meninggalnya atau tidak mampu menjalani lagi (incapacity) profesinya sang dokter.

6) Sudah selesainya kewajiban dokter seperti ditentukan di dalam kontrak.

7) Dalam kasus gawat darurat, apabila dokter yang mengobati atau dokter pilihan pasien sudah datang, atau terdapat penghentian keadaan kegawat-daruratannya.

8) Lewat jangka waktu, apabila kontrak medik itu ditentukan untuk jangka waktu tertentu. 


\section{Tahkím}

Vol. XIV, No. 2, Desember 2018

9) Persetujuan kedua belah pihak antara dokter dan pasiennya bahwa hubungan dokter dan pasien itu sudah diakhiri. ${ }^{31}$

\section{Perlindungan Hukum Bagi Pasien Akibat Perjanjian Terapeutik}

Perlindungan terhadap Pasien dapat dilihat dalam Undang-Undang RI Nomor 36 Tahun 2009 tentang Kesehatan, Undang-Undang RI Nomor 29 Tahun 2004 Tentang Praktek Kedokteran, dan Undang-Undang RI Nomor 8 Tahun 1999 Tentang Perlindungan Konsumen. Perlindungan terhadap Pasien menurut Undang- Undang RI Nomor 36 Tahun 2009 tentang Kesehatan terdapat pada pasal:

Pasal 56

1. Setiap orang berhak menerima atau menolak sebagian atau seluruh tindakan pertolongan yang akan diberikan kepadanya setelah menerima dan memahami informasi mengenai tindakan tersebut secara lengkap.

2. Hak menerima atau menolak sebagaimana dimaksud pada ayat (1) tidak berlaku pada:

a. penderita penyakit yang penyakitnya dapat secara cepat menular ke dalam masyarakat yang lebih luas;

b. keadaan seseorang yang tidak sadarkan diri; atau

c. gangguan mental berat.

3 Ketentuan mengenai hak menerima atau menolak sebagaimana dimaksud pada ayat (1) diatur sesuai dengan ketentuan peraturan perundang-undangan.

\section{Pasal 57}

1. Setiap orang berhak atas rahasia kondisi kesehatan pribadinya yang telah dikemukakan kepada penyelenggara pelayanan kesehatan.

2. Ketentuan mengenai hak atas rahasia kondisi kesehatan pribadi sebagaimana dimaksud pada ayat (1) tidak berlaku dalam hal:
a. perintah undang-undang;
b. perintah pengadilan;
c. izin yang bersangkutan;
d. kepentingan masyarakat; atau
e. kepentingan orang tersebut.

Pasal 58

1. Setiap orang berhak menuntut ganti rugi terhadap seseorang, tenaga kesehatan, dan/atau penyelenggara kesehatan yang menimbulkan kerugian akibat kesalahan atau kelalaian dalam pelayanan kesehatan yang diterimanya.

2. Tuntutan ganti rugi sebagaimana dimaksud pada ayat (1) tidak berlaku bagi tenaga kesehatan yang melakukan tindakan penyelamatan nyawa atau pencegahan kecacatan seseorang dalam keadaan darurat.

\footnotetext{
${ }^{31}$ J. Guwandi, Dokter, Pasien dan Hukum (Jakarta: Fakultas Kedokteran UI, 1996), h.24-26.
} 


\section{Tahkím}

Vol. XIV, No. 2, Desember 2018

3. Ketentuan mengenai tata cara pengajuan tuntutan sebagaimana dimaksud pada ayat (1) diatur sesuai dengan ketentuan peraturan perundang-undangan.

Perlindungan hukum yang dapat diberikan terhadap pasien menurut UndangUndang Praktek Kedokteran dapat tercermin dari hak dan kewajiban pasien yang terdapat dalam pasal pasal 52 dan pasal 53 sebagaimana telah dijelaskan sebelumnya, bahwa perlindungan hukum terhadap pasien menurut Undang-Undang RI Nomor 8 Tahun 1999 Tentang Perlindungan Konsumen, terlebih dahulu dijelaskan tentang pengertian konsumen. Dalam Undang-Undang Perlindungan konsumen, pada pasal 1 angka 2 menyebutkan bahwa konsumen adalah "Setiap orang pemakai barang dan/ atau jasa yang tersedia dalam masyarakat, baik bagi kepentingan diri sendiri , keluarga, orang lain, maupun makhluk hidup lain dan tidak untuk diperdagangkan."

Di sini konsumen itu bukan hanya pemakai barang saja melainkan juga pemakai jasa. Jasa adalah "setiap layanan yang berbentuk pekerjaan atau prestasi yang disediakan bagi masyarakat untuk dimanfaatkan oleh konsumen." 32 Dari pengertian ini dapat disebutkan bahwa pasien juga termasuk ke dalam konsumen. Pasien sebagai konsumen memiliki hak dan kewajiban yang merupakan bentuk perlindungan hukum, yaitu antara lain: ${ }^{33}$

Hak konsumen adalah:

a. hak atas kenyamanan, keamanan dan keselamatan dalam mengkonsurnsi barang dan/atau jasa;

b. hak untuk memilih barang dan/atau jasa serta mendapatkan barang dan/atau jasa tersebut sesuai dengan nilai tukar dan kondisi serta jaminan yang dijanjikan;

c. hak atas informasi yang benar, jelas, dan jujur mengenai kondisi dan jaminan barang dan/atau jasa;

d. hak untuk didengar pendapat dan keluhannya atas barang dan / atau jasa yang digunakan;

e. hak untuk mendapatkan advokasi, perlindungan, dan upaya penyelesaian sengketa perlindungan konsumen secara patut;

f. hak untuk mendapat pembinaan dan pendidikan konsumen;

g. hak untuk diperlakukan atau dilayani secara benar dan jujur serta tidak diskriminatif;

h. hak untuk mendapatkan komnpensasi, ganti rugi dan/atau penggantian, apabila barang dan/atau jasa yang diterima tidak sesuai dengan perjanjian atau tidak sebagaimana mestinya;

i. hak-hak yang diatur dalam ketentuan peraturan perundang-undangan lainnya.

\footnotetext{
${ }^{32}$ Lihat pasal 1 angka 5 Undang-Undang RI Nomor 8 Tahun 1999 Tentang Perlindungan Konsumen.

${ }^{33}$ Lihat pasal 4 dan 5 Undang-Undang RI Nomor 8 Tahun 1999 Tentang Perlindungan Konsumen
} 


\section{Tahkím}

Vol. XIV, No. 2, Desember 2018

Kewajiban konsumen adalah:

a. membaca atau mengikuti petunjuk informasi dan prosedur pemakaian atau pemanfaatan barang dan/atau jasa, demi keamanan dan keselamatan;

b. beritikad baik dalam melakukan transaksi pembelian barang dan/atau jasa;

c. membayar sesuai dengan nilai tukar yang disepakati;

d. mengikuti upaya penyelesaian hukum sengketa perlindungan konsumen secara patut.

Di sini juga diatur tentang kewajiban pelaku usaha untuk memberikan ganti rugi atas kerusakan, pencemaran, dan/atau kerugian konsumen akibat mengkonsumsi barang dan/atau jasa yang dihasilkan atau diperdagangkan. Ganti rugi sebagaimana tersebut dapat berupa pengembalian uang atau penggantian barang dan/atau jasa yang sejenis atau setara nilainya, atau perawatan kesehatan dan/atau pemberian santunan yang sesuai dengan ketentuan peraturan perundang-undangan yang berlaku. ${ }^{34}$

\section{Kesimpulan}

Kedudukan hukum antara para pihak yaitu dokter dan pasien dapat terlihat dari bagaimana hubungan hukum diantara mereka. Hubungan antara dokter dan pasien adalah suatu hubungan yang kompleks, karena didalamnya terdapat hubungan medik, hubungan moral maupun hubungan hukum. Pada hubungan medic dan moral, dokter memiliki kedudukan yang sangat tinggi, karena dokter adalah orang yang sangat tahu tentang penyakit pasien, sedangkan pasien memiliki kedudukan yang sangat lemah yaitu orang yang sedang sakit dan awam dengan penyakitnya. Pasien datang ke rumah sakit atau ke dokter berharap agar segera disembuhkan penyakitnya. Pola hubungan ini disebut dengan hubungan paternalistic, dimana dokter dianggap lebih tahu dan mampu mengobati pasiennya. Dalam perkembangannya, pola hubungan antara dokter dan pasien yang demikian tersebut, lambat laun telah mengalami pergeseran ke arah yang lebih demokratis yaitu kearah hubungan berdasarkan kontraktual. Sebagaimana hubungan kontraktual terdapat hak dan kewajiban yang sama antara kedua belah pihak. Kedudukan dokter tidak lagi dianggap lebih tinggi daripada pasien melainkan kedudukan dokter dan pasien dalam hubungannya tersebut sudah seimbang atau sederajat. Pasien tidak lagi dianggap sebagai objek hukum tetapi pasien sudah sebagai subjek hukum. Pola hubungan ini seperti yang dijelaskan diatas disebut dengan pola hubungan hukum.

Hubungan hukum antara dokter dan pasien menempatkan kedudukan dokter dan pasien berada pada posisi yang sejajar atau seimbang, sehingga setiap apa yang dilakukan oleh dokter terhadap pasien tersebut harus melibatkan pasien dalam menentukan apakah sesuatu tersebut dapat atau tidak dapat dilakukan atas dirinya.

\footnotetext{
${ }^{34}$ Lihat pasal 19 ayat 1 dan 2 Undang-Undang RI Nomor 8 Tahun 1999 Tentang Perlindungan
} Konsumen. 


\section{Tahkím}

Vol. XIV, No. 2, Desember 2018

Salah satu bentuk keseimbangan dalam hubungan hukum dokter dan pasien adalah melalui informed consent atau persetujuan tindakan kedokteran.

Perlindungan hukum bagi pasien akibat perjanjian terapeutik secara yuridis dapat terlihat dalam Undang-Undang Nomor 36 Tahun 2009 Tentang Kesehatan, Undang-Undang Nomor 29 Tahun 2004 Tentang Praktek Kedokteran dan UndangUndang Nomor 8 Tahun 1999 Tentang Perlindungan Konsumen.

\section{DAFTAR PUSTAKA}

Chazawi, Adami. Malapraktik Kedokteran, Jakarta: Sinar Grafika, 2016.

Dahlan, Sofyan. Hukum Kesehatan, Cet. 3; Semarang; Badan Penerbit Universitas Diponegoro, 2003.

Guwandi, J. Dokter, Pasien, dan hukum", (Jakarta; Fakultas Kedokteran Universitas Indonesia, 1996)

Hariyani, Safitri. Sengketa Medik. Alternatif Penyelesaian Perselisihan Antara Dokter Dan Pasien, Jakarta: Diadit Media, 2005.

H.S., Salim. Perkembangan Hukum kontrak di Luar KUH Perdata, Jakarta: PT Raja Grafindo Persada, 2006.

-------. Hukum Kontrak, Teori Dan Teknik Penyusunan Kontrak, Jakarta: Sinar Grafika, 2010.

Komalawati, Veronica. Peranan Informed Consent dalam Transaksi Terapeutik, Bandung: PT. Citra Aditya Bakti, 1999.

Miru, Ahmadi. Hukum Kontrak. Perancangan Kontrak, Jakarta: Raja Grafindo Persada, 2007

Miru, Ahmadi dan Sakka Pati. Hukum Perikatan. Penjelasan Makna Pasal 1233 Sampai Pasal 1456, Jakarta: Raja Grafindo Persada, 2008.

Muhammad, Abdulkadir. Hukum Perikatan, Bandung: Citra Aditya Bakti, 1992.

Nasution, Bahder Johan. Hukum Kesehatan, Jakarta: Rineka Cipta, 2005.

Prakoso, Djoko dan Bambang Riyadi Lany. Dasar Hukum Persetujuan Tertentu di Indonesia, Jakarta: Bina Aksara, 1987.

Rahardjo, Handri. Hukum Perjanjian di Indonesia, Jakarta: Pustaka Yustisia, 2009.

Saherodji, H. Hari. Pokok-Pokok Hukum Perdata, Jakarta; Aksara Baru, 1980.

Supriadi, Wila Chandrawila. Hukum Kedokteran, (Bandung; Mandar Maju, 2001)

Yanlua, Mohdar dan Evy Savitri Gani. Hukum Dagang, Magetan: Media Guru, 2015.

Undang-Undang:

Kitab Undang-Undang Hukum Perdata

Undang-Undang RI Nomor 36 Tahun 2009 Tentang Kesehatan 


\section{Tahkím}

Vol. XIV, No. 2, Desember 2018

Undang-Undang RI Nomor 29 Tahun 2004 Tentang Praktek Kedokteran

Undang-Undang RI Nomor 36 Tahun 2014 Tentang Tenaga Kesehatan

Undang-Undang RI Nomor 8 Tahun 1999 Tentang Perlindungan Konsumen

Peraturan Menteri Kesehatan RI Nomor 290/MENKES/PERIII/2008 Tentang Persetujuan Tindakan Kedokteran.

Perjanjian terapeutik diakses pada http://4lhamid.blogspot.co.id/2012/12/kontrakperjanjian-terapeutik.html (diakses tanggal 29 November 2017 pukul 18.00 wit)

Pengertian Transaksi Terapeutik Definisi Tujuan Dasar Hukum dalam Pelayanan Medis diakses dalam http://www.landasanteori.com/2015/10/pengertian-transaksiterapeutik. html (diakses tanggal 25 November 2017 pada pukul 20.00 wit) 